Journal of Social Sciences 5(2): 85-94, 2009

ISSN 1549-3652

(C) 2009 Science Publications

\title{
The Effect of Learning Styles on Education and the Teaching Process
}

\author{
İbrahim Yaşar Kazu \\ Faculty of Technical Education, Department of Educational Sciences, \\ Firat University, 23119 Elazig, Turkey
}

\begin{abstract}
Problem statement: It is of great importance that individuals actively participate in the learning process; that, starting from the early ages, their awareness be raised about the efficiency of the learning styles in developing their academic success and self-confidence; and that the learning styles they have be determined. For this reason, this study aimed to reveal the learning styles having great importance for succeeding in the learning process and to determine the efficiency of these styles in learning process. Approach: The purpose of this study was to determine the effect of learning styles on education and the teaching processes. This empirical research served two key purposes: First purpose was to detect the impacts of the learning styles on teaching and learning methods and second purpose was to evaluate the key models in a variety of learning environments to better understand their merits and deficiencies. In this regard, after emphasizing "learning style" concept, this study examined the conceptual and applied researches that can explain the effects of learning styles on teaching and learning processes. Results: Education should help raising individuals who are able to look at the world from various perspectives. Individual differences should be taken into consideration in achieving these objectives. Education should be given by taking these differences into consideration in the educational and instructional processes. Individual brings some latent potencies produced by the genetic heritage; these latent potencies may be modified or develop by social acculturation in time. Conclusion: To provide the best way of learning to the individuals, learning style should be determined beforehand by considering the differences such as personality, perception, ability and intelligence.
\end{abstract}

Key words: Learning styles, Kolb's learning style, multiple intelligences theory, classroom environment, primary education

\section{INTRODUCTION}

Before examining the learning styles and models, it is necessary to explain "What is the key concept in learning style?" and "What does style mean?" Style is a concept used in the fields of fashion, art, sports and media.. From this point of view, individual's preferences are central. When this concept is considered in educational content, it is seen that every student has his/her own learning style. These differences (personality, perception, ability, intelligence) affect students' motivation and attitudes towards the lessons. As a result, these differences affect the effectiveness of the lesson. Beside those, the student's gender, intelligence and personal characteristics influence the learning style as well ${ }^{[1]}$. As the learning style is related to individual characteristics and preferences, learning styles reflect the students' preferences on how they perceive the environment, interact with this environment, react and experience learning in this process. When individual learning styles are determined, both the kind of the teaching environment they need to be in and the way to precisely determine the issues to be learned inside and outside of the class may be raised ${ }^{[3]}$. When the lessons are taught by taking into consideration the individuals' learning styles; their interests and successes increase considerably. What is important here is that learning styles are neither better nor worse than each other. If a teacher keeps this matter in mind, s/he can turn this difference into an advantage. To achieve this purpose, studies have been conducted over the past 40 years. In this regard, after emphasizing the concept of learning style, this study examined the conceptual and applied researches that can explain the effects of learning styles on the processes of education and learning. These studies are shown in Table 1.

Table 1 is based on a classification made by analyzing the variables used by different authors in defining learning styles. Selected authors are grouped according to years as well as the similarities of the variables they used.

McCarthy ${ }^{[4]}$ described "learning styles" as the individual's perception and use of the knowledge." McCarthy takes the fundamental of the learning style 
Table 1: Different learning styles and some basic variables

\begin{tabular}{|c|c|c|c|}
\hline Person & Year & Description & Basic variables \\
\hline Keefe & 1979 & $\begin{array}{l}\text { Learning styles are cognitive, affective and psychological } \\
\text { characteristics that learners use as constant determinants } \\
\text { to some extent in their perception, interaction and reaction } \\
\text { styles }^{[21,41]}\end{array}$ & $\begin{array}{l}\text { Some research, has handled the learning styles } \\
\text { as a specific learning manner, personal and } \\
\text { distinguishing characteristic show how the } \\
\text { student will begin to act and how s/he will }\end{array}$ \\
\hline $\begin{array}{l}\text { Dunn and } \\
\text { Dunn }\end{array}$ & 1993 & $\begin{array}{l}\text { Learning style is a way of getting and processing the } \\
\text { knowledge starting with the learners' dealing with new } \\
\text { and difficult information }\end{array}$ & $\begin{array}{l}\text { behave in the learning environment. Learning } \\
\text { style is different and distinct for each student. } \\
\text { Learning style is defined as the total of the }\end{array}$ \\
\hline $\begin{array}{l}\text { Dunn and } \\
\text { Dunn }\end{array}$ & 1978 & $\begin{array}{l}\text { Learning style is comprised of eighteen elements which } \\
\text { are designed according to four basic stimuli having } \\
\text { relations with the person's adequacy in assimilating } \\
\text { and acquiring a subject. The coherence and variation } \\
\text { of these components show that few people learn in the } \\
\text { same way }\end{array}$ & $\begin{array}{l}\text { learner's characteristics according to the } \\
\text { generating in the origin of the individual } \\
\text { differences in learning environment. }\end{array}$ \\
\hline Keefe & 1987 & $\begin{array}{l}\text { Learning style is all of the cognitive, affective and } \\
\text { psychological characteristics which reflect the individual's } \\
\text { perceptions on his/her environment }\end{array}$ & \\
\hline Reinert & 1976 & $\begin{array}{l}\text { The learning style of an individual is the style s/he aims at } \\
\text { learning actively, it is the style which the individual } \\
\text { uses and develops ways to take in, retain the new } \\
\text { information, put it for later use }{ }^{[24]} \text {. }\end{array}$ & $\begin{array}{l}\text { Learning style is a kind of inner program that } \\
\text { shapes our behavior. This program differs from } \\
\text { one person to another and it takes individuality } \\
\text { into account. }\end{array}$ \\
\hline Entwistle & 1981 & $\begin{array}{l}\text { Learning style is the tendency to absorb a special } \\
\text { strategy. }\end{array}$ & $\begin{array}{l}\text { Those four terms(temperament, general } \\
\text { education, general tendency, harmony) affect } \\
\text { the consistency and the coherence in } \\
\text { meaningful amount }\end{array}$ \\
\hline Kolb & 1984 & $\begin{array}{l}\text { Learning styles are measured by a self-announced scale, } \\
\text { known as LSI and LSI. Differences in learning ways are } \\
\text { based on the four kinds of learning processes in relation } \\
\text { to each other. }\end{array}$ & \\
\hline Schmeck & 1983 & $\begin{array}{l}\text { Learning style is a student's own tendency to absorb } \\
\text { a special learning strategy independent from the } \\
\text { environment }^{[10]}\end{array}$ & \\
\hline $\begin{array}{l}\text { Della-Dora } \\
\text { and Blanchard }\end{array}$ & 1979 & $\begin{array}{l}\text { Learning style is a personal and preferred way in } \\
\text { assimilating the knowledge and the experience in the } \\
\text { learning situation independent from the context }{ }^{[45]} \text {. }\end{array}$ & $\begin{array}{l}\text { Some research suggests that the individual's } \\
\text { tendency to act in a specific way can be } \\
\text { counted as "preferences" which are highly }\end{array}$ \\
\hline $\begin{array}{l}\text { Jonassen and } \\
\text { Grabowski }\end{array}$ & 1993 & $\begin{array}{l}\text { Learning styles consist of the learner's preferences in } \\
\text { different educational and instructional activities. These } \\
\text { are the general tendencies which are preferred in } \\
\text { processing data in different ways }{ }^{[42]} \text {. }\end{array}$ & related to the differences of individuals. \\
\hline Legendre & 1998 & $\begin{array}{l}\text { Learning style is the person's style in learning, solving } \\
\text { a problem, thinking and the style s/he likes reacting in } \\
\text { within an educational situation }{ }^{[30]} \text {. }\end{array}$ & \\
\hline $\begin{array}{l}\text { Felder and } \\
\text { Silverman }\end{array}$ & 1988 & $\begin{array}{l}\text { Learning style is the characteristic difficulties and } \\
\text { preferences in the process of an individual's acquiring } \\
\text { knowledge, holding and processing it. }\end{array}$ & \\
\hline
\end{tabular}

model from Kolb's learning style. McCarthy categorizes learning styles into four groups. The learners of the first group are the imaginative learners, of the second group are the analytical learners, of the third group are the common sense learners and the forth group are the dynamic learners ${ }^{[4]}$.

According to Kaplan and Kies ${ }^{[11]}$, the learning style is an inborn characteristic which does not easily change during the lifetime, but can change and be developed during the life of the individual through the experiences. This affects the individual while walking, lying, sitting, speaking, playing and writing. Actions are made according to these characteristics ${ }^{[12]}$. Besides this, learning style has an important place in learning how to study ${ }^{[13]}$.

Grasha $^{[14]}$ developed another model based on the importance of preferences in learning. He describes "learning style" as the collective experience of learning during the process of gaining knowledge ${ }^{[15]}$. Gregorc thinks that being aware of yourself helps in determining your real learning style.

According to Butler ${ }^{[17]}$ who is much influenced by Gregorc, learning style is a general concept which highlights the learning differences like the quality of an umbrella. Every individual has a different style. This 
can be in clothes worn, the music listened and the colors selected by and the friends and social groups of the individuals. Those different individual styles help the individual to identify a learning style.

According to Allport ${ }^{[18]}$, learning style is defined as perception, thought, remembering or problem-solving of the individual in the way that $\mathrm{s} / \mathrm{he}$ is used to do. It is assumed that these definitions include cognitive processes and the individuals use the learning style that they are used to ${ }^{[19]}$. Allport, in his study of learning styles, used the style concept in 1930 and then in 1961. $\mathrm{He}$ also concentrated on the individual differences among students ${ }^{[20]}$.

Learning style according to Keefe: By taking advanced cognitive processes, Keefe has explained lasting cognitive, affective and physiological characteristics after researching how the student perceived the environment and how s/he interacted with his/her learning environment. He has also stated that the individual with these aforementioned style characteristics is under the influence of the genetic code, personal development and strong environmental adaptation. According to him, learning styles has cognitive, affective and environmental aspects ${ }^{[21]}$.

Kolb's learning style: Kolb's Experiential Learning Theory constitutes the basis of the Kolb learning style model. Experiential learning which differs from other cognitive learning theories explores the use of experiences in the learning process ${ }^{[22]}$. With this start, he has developed his studies following on Lewin's experiential learning theory. As a result, a learning style model has been developed. Kolb defines learning as the process of being in harmony with the social and physical environment. He has proceeded to define "learning" and differentiate it from knowledge. According to Kolb, learning is a process and knowledge is the transformation of the experience ${ }^{[17,23-27]}$.

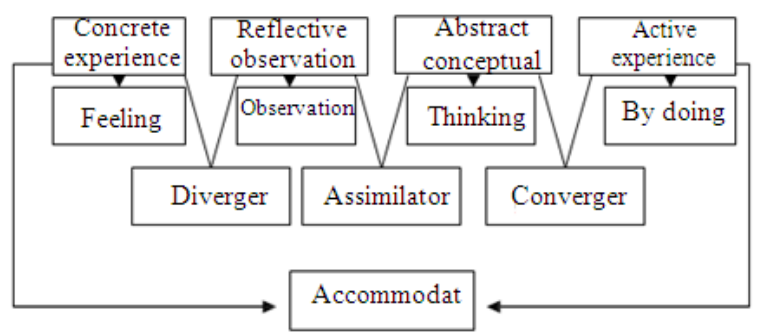

Fig. 1: Kolb's learning style model
When Kolb realized the classification in the Table 1, he made use of Jung's Psychological Types Theory. That is, the "concrete-abstract" domain in Kolb's learning style resembles with the "perceptual-intuitive" domain in Jung's Model.

It is possible to come up in daily life with the terms focused on in Kolb's Learning Style. As people have various learning styles and points of view in the life, some people learn through feeling, thinking, watching and doing. Kolb has further elaborated his ideas. The individuals who have an abstract style try to comprehend the real world through relating this approach to events. While a concrete style works through feeling, a reflective style works through watching and besides these an active style works through doing and experiencing ${ }^{[28]}$. On the other hand, the "active-reflective" domain takes part in both models ${ }^{[29]}$. Taking a different approach to that of Jung, Kolb has classified the learning styles, ways and manners in Fig. 1. Kolb has defined four types of learning styles. These are:

Accommodator: Planning and carrying out decisions characterize the individual who has this kind of learning style. They adjust to changes since they are openminded in the learning environment. The learning occurs by doing and experiencing actively. They are always in a state of invention.

Assimilator: Creating conceptual models and reflective observations are their specific characteristics. In other words, creating conceptual models, focusing on abstract concepts and ideas during the learning process are their specific characteristics.

Converger: The characteristic of this learning style is that individuals rely on abstract conceptualization and concrete experience. So they need to perceive the whole and moving from the whole to the parts.

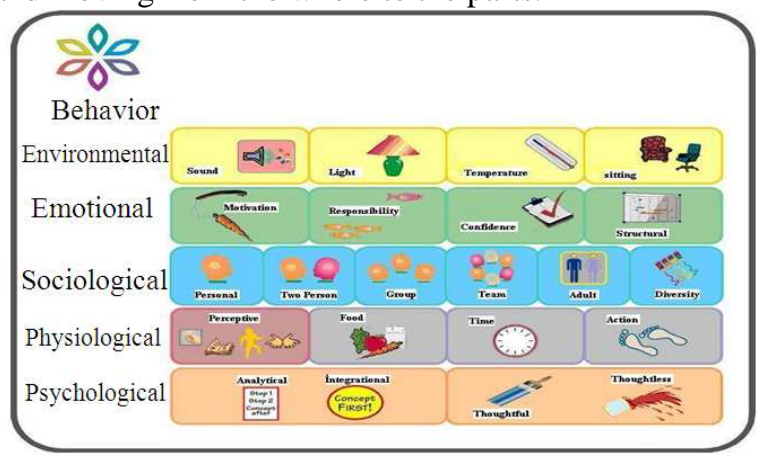

Fig. 2: Dunn and Dunn's learning styles model 
Diverger: Thinking, being aware of values and meanings, concrete experience and learning through reflective observation are the main characteristics. They adjust by observing concrete situations from different angles. They construct their ideas patiently, objectively and carefully in the learning process. But they avoid action while taking their ideas into consideration, and at the same time they are aware of their own feelings and ideas. The reason why this learning style is called diverger is that individuals bring different ideas together and they show a better performance when desired.

Learning style according to Dunn and Dunn: Dunn and Dunn have taken some developmental characteristics into consideration while determining learning styles. These are biological and individual developmental characteristics. Because of the differences coming from these biological and individual developmental characteristics, some ways can be found to make instruction appropriate. In other words, some students learn through hearing, some through experiencing and some primarily through watching. According to Dunn \& Dunn, the important thing is that teacher has to determine the ways by which the student learns in the process ${ }^{[31,46,48]}$.

When we examine the stimuli in Fig. 2 and the contribution that they will make in education, the following emerges:

- If a student says "sssshhh", if s/he shuts his/her ears to the noise and sound, if s/he gestures a "be quiet!" with his/her hand, it shows that s/he wants to be alone. For these students, families should place the study area free and away from noise. The teacher should know that it is not possible to study in noisy places. The teacher should also keep in mind that s/he shouldn't sit such students in noisy places while making the seating plan

- It is often not recognized at the beginning that some students are uneasy when they come into class. After a while teacher should observe whether the student prefers a dimly-lit environments, if $\mathrm{s} / \mathrm{he}$ narrows his/her eyes or keeps blinking, if $\mathrm{s} / \mathrm{he}$ avoids the sun and light or turns his/her back to an open window. The opposite of this should also be considered. Students may prefer a richly-lit environment

- Some students want a comfortable learning environment as the one they have at home. For example, if the student climbs on top of the table and crosses his/her legs, if s/he leaves his/her desk or table untidy, if s/he lies down, then s/he most probably prefers an informal environment to a planned one. Of course, educational environments are formal institutions; this kind of behavior will not be allowed. If every student behaves as informally as they might at home, it would be impossible for the teacher to control the class

- Some students in the class use their visual memory well. For example, if a student looks at the picture which the teacher draws carefully, and if $\mathrm{s} / \mathrm{he}$ concentrates on the picture much more than the topic, these students are likely to be visual students ${ }^{[26,33]}$

- If a student is complaining about the heat, if $s / h e$ is moving constantly when it is hot, if s/he walks with his/her coat unbuttoned in cold weather, s/he probably likes to study in the cold. But if $\mathrm{s} / \mathrm{he}$ complains about the cold, if s/he wears extra clothes, then s/he doesn't prefer a cold learning environment. If s/he doesn't concentrate on visual and auditory activities s/he is probably kinesthetic

- If a student is shifting constantly in his/her seat, if s/he keeps standing up or constantly asking permission to leave, s/he is probably a dynamic student

- The student is probably an auditory student ,if s/he uses auditory stimuli, that is if s/he chooses materials like a cassette tape or a CD player while $\mathrm{s} / \mathrm{he}$ is playing, if $\mathrm{s} / \mathrm{he}$ is not interested in drawings while reading, if $\mathrm{s} / \mathrm{he}$ pays attention to details during conversations, if $\mathrm{s} / \mathrm{he}$ remembers what $\mathrm{s} / \mathrm{he}$ heard, if s/he likes dialogues when the teacher explains a topic in class ${ }^{[2]}$

- Some students want to eat constantly while studying. They need to gobble while learning. But some students, who are silent and relaxed, have no need to eat anything while learning

Dunn and Dunn state that the difference between learning styles result from the abovementioned student profiles. Different students will want to be passive visually and auditory, to learn by themselves, or to learn by just listening. Those can be sometimes enough for them for academic achievement. However, tactile or kinesthetic students are the ones who need dynamism and who prefer to learn with their peers and, the reason for their success is related to the nature of the school environment.

As a result, there are many compelling reasons why learning styles must be kept in mind in the education and training process. These can be summarized and itemized as follows: 
- When an individual's learning style is known, it means that every individual can be perceived as different from the others. That is, the individual will create his/her own learning style. As perception frequencies of the brain differ, individuals interpret stimuli, drawing on sensory memory. When characteristics like age and gender are known, their differences are recognized. A teacher who is aware of his/her students' learning styles is the one who will serve the objectives of the education

- Recognizing the student's learning style contributes to effectiveness. The effectiveness will decrease if the student learns in an environment, incompatible with his/her learning style

- Although education is student-centered today, some tendency towards a teacher-centered education commitment of the past still exists. As a consequence of this, student's interests, expectations and needs are ignored. But something that must be kept in mind in the education process is the idea that every individual behaves according to his/her personal needs and that $\mathrm{s} / \mathrm{he}$ is responsible for his/her learning. However, it is because of the fact that learning is a personal process. This is one of the reasons demanding that learning styles should be taken into consideration in the education and teaching process

- The purpose of multiple intelligences theory and constructivism recently applied in education and the aim of teaching is to encourage the students to acquire knowledge according to their own learning styles by giving them a variety of work and projects. As seen in Fig. 3 and explained in the theory of multiple intelligences, individuals have different intelligences. Individual learns according to his/her dominant type of intelligence. The important thing for the teacher is to do activities in the class according to the dominant type of intelligence in the student's learning style. In this way, the student will be more active in the class since these activities are appropriate to his/her learning style

- As the realization that the student cannot learn comprehensively in an environment in which "teacher" is the only active person and the student is always passive one, the awareness of learning styles in the education and teaching process has become much more important

The majority of the students can not be reached when ordinary and monotonous methods and techniques which do not handle a learning unit with different learning teaching approaches are used in the class. It must be kept in mind that each individual is different from the others and learns through different methods and techniques. The abovementioned points are listed to demonstrate the importance of learning styles in education and in teaching process. Thus, it may be understood that learning styles have become a very important field of research. This study is a part of this awareness.

Why is learning style important? It is very important for an individual to know his/her learning style. The reason is that one of the most significant issues in learning to learn, or in becoming effective in the process of learning, is an individual's taking the responsibility for his/her own learning. For this purpose, the individuals should know what their own learning styles are and what characteristics this style has and they should thereby behave according to this style. In this way, the individual can acquire the constantly changing and increasing amount of information without need for the assistance of others $^{[32-34]}$.

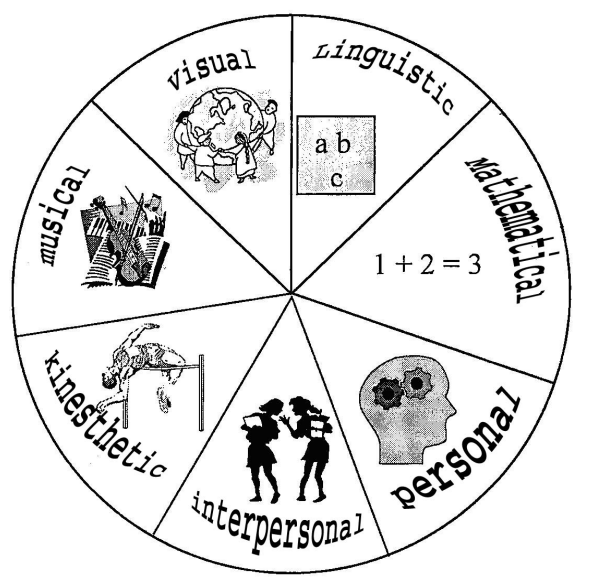

Fig. 3: Intelligences in the theory of multiple intelligences

When the learner takes the responsibility of his/her own learning, s/he attributes meaning to the process of learning. S/he develops an understanding of his/her own form of learning style and becomes much more satisfied with the environment $\mathrm{s} / \mathrm{he}$ interacts with. Every opportunity for learning is a chance for him/her. It is in the learner's hand to use different ways and develop the learning styles to some extent.

Learning style is important for many reasons; however, there are three vital ones. First of all, people's learning styles will vary because everyone is different from one another naturally. Secondly, it offers the 


\section{J. Social Sci., 5(2): 85-94, 2009}

opportunity to teach by using a wide range of methods in an effective way. Sticking to just one model unthinkingly will create a monotonous learning environment, so not everyone will enjoy the lesson. In other words, learning and teaching will be just words and not rooted in reality. Thirdly, we can manage many things in education and communication if we really recognize the groups we are called to. Of course, we may not know every detail; however, being aware of our students' learning styles, psychological qualities and motivational differences will help us regulate our lessons appropriately and according to the conditions ${ }^{[4-}$ $43,44,45,47]$

The advantages of identifying learning styles: The research on learning styles shows that individuals have another learning style besides the dominant one. In other words, an individual has one or more than one learning styles. When the individual has more than one learning style, the levels of using it can change ${ }^{[35]}$.

Learning style has cognitive, affective and psychological aspects. Cognitive components are about the internal control of the system of running the knowledge and these can be changed through education. Affective and psychological components affect the preferences of the individual, and suggest answers to both education and teaching strategies ${ }^{[36]}$. Learning style gives opportunities to recognize individuals and the differences between them. For this reason, a teaching style is required to devise learning approaches that take cognitive, affective and psychological factors into account ${ }^{[37]}$.

Learning style has an important place in the lives of individuals. When the individual knows his/her learning style, s/he will integrate it in the process of learning so s/he will learn more easily and fast and will be successful ${ }^{[34]}$. Another advantage of the identification of the own learning style by the student is that it will help the student to become an effective problem solver. The more successful the individual is at solving the problems s/he faces, the more control s/he will take over his/her own life ${ }^{[38]}$.

It is important that individuals receive education in areas suitable for their learning styles. A person educated in an area having no relationship to his/her learning style may lack confidence and s/he may be less successful; s/he may as a result become frustrated. Knowledge of learning style also provides information to the student as to why s/he has learnt in a different way than others. It helps to control the process of learning. It is vital because one of the most important signals in learning is to learn to be autonomous, that is, for the individual to take responsibility for his/her own learning. Because of this, s/he should know what learning style is. This has to be part of the learning process to enable the individual to obtain knowledge, which constantly shifts and changes, without any help from others.

Briefly, confidence in learning will consistently rise when learners know how to learn. Learning to learn and grasping knowledge in a suitable manner will lessen the need for an overbearing control by teachers. At this point, teachers guide the students. The students take responsibility for their learning, they are at the center of the process and everything is under their control. They search answers to the problems and benefit from their unique performances and preferences in their learning styles. Those people will identify their aims, unlike those whose learning style preferences are not identified. They know what they want to learn and "how". This awareness will change their perspectives on learning new things.

\section{RESULTS}

Learning style, which can be counted as one of the techniques used for recognizing individuals, will especially assist the teachers in getting to know the group of students in front of them and pave the way for them to become much more effective. Research on this subject has suggested that the students who have experienced this learning process and approach will be more successful. This could have a great impact on learning.

To achieve this success, both teachers and students should undertake many responsibilities, but the heaviest responsibility is on the teachers. The teachers should match teaching style and learning tasks to individual learners' preferred styles and provide a range of input styles and learning tasks so that the learners will sometimes get a task in their preferred style, sometimes in the other styles, so that they can improve. Lastly, the teachers should help the students to move from one less successful style to another by using teaching styles and thinking skills. The teachers should be concrete and practical, concerned with application. They should support the students' imagination, creativity and exploration of new possibilities. In other words, the teachers should teach them to be critical and challenging. It is not so difficult to understand the learning styles and recognize them. The important thing is to recognize the students' learning style. Studying with knowledge of the learning style helps an individual to reach his/her goals quickly. 


\section{J. Social Sci., 5(2): 85-94, 2009}

Considering the classroom, one should know that classroom environment is a place full of various stimuli. But it should be remembered that teaching is an art of instruction. The teacher has to maximize the stimuli as much as possible. Students with these different styles will be affected not only by the stimuli in the classroom but also by the stimuli at home. When the teacher discovers these styles of the students and shares this with the parents, s/he will ensure that learning serves its goal. That is, for a student with an auditory learning style, the teacher should ask parents to provide the student with a room or desk away from noise. The goal is to realize learning and to encourage the student to revise outside of school, at home, after eliminating any negative situations. In this way, the student will transfer the learning into the real life.

\section{DISCUSSION}

While learning style has been discussed mostly on an academic level in Turkey, many developed countries use it to improve the quality of education. We need to make improvements to reach that point. The aim should be to identify individuals learning styles and to provide more effective learning.

People responsible for the education of students need to follow these developments. For example, Özbek's ${ }^{[3]}$ study "determining learning styles of primary school students" -one of the studies conducted on this issue- suggests that when teachers need information about the learning styles of the students, they can get results by applying a learning style inventory and with these results they can choose instruction models and obtain the necessary materials. Teachers can share the results with parents and inform them about how they can help their children learn at home. Another study by Çelenk and Karakış ${ }^{[39]}$, The Level of the Students Attending Universities and Having Different Learning Styles, states that students are concentrated on the converger learning style. The main feature of it is reflective observation and abstract conceptualization. The teacher has to realize that:

- $\mathrm{S} /$ he has to plan the lesson according to different learning styles and concentrate on students having different learning styles equally

- Even if learning levels differ, the preferences of students about learning styles do not change

Teachers have to work to provide a high-quality education by heeding the results of the studies and explanations above. The research studies will assist the teachers in remembering what needs to be done. The research repeatedly emphasizes that the classroom environment at every educational level should be organized according to learning styles.

That is especially the case at the first level of primary education, when the teacher runs the activities; s/he needs to pay close attention to the student closely, and needs to devise activities that will determine a student's learning style. For example, a teacher who has a student with a tactile learning style has to know that the student records the information through his/her feelings. Similarly, a student with auditory learning style stores the information in his/her brain through voices and listening. A visual student learns through images, not through voices. The seating plans for individuals with different learning styles are quite important. Some students with different learning styles shouldn't be seated in noisy places for exams. At the same time too little or too much light among the "visuals" can effect learning negatively. As for "tactiles", a comfortable outfit, and the attitudes of people from inside and outside affect their approaches to learning. Concerning this, Dunn and Dunn ${ }^{[40]}$ explained that younger students' perceptional preferences are mostly tactile or physical and that the teacher needs to take this into consideration. As a result of their studies on visual and auditory preferences, Dunn and Dunn suggested that less than $12 \%$ of the students in the first level of primary education have an auditory learning preference while $40 \%$ of the students have visual learning preferences. As a result of these findings, it can be seen that a change occurs in the learning of the students with visual and auditory perception in relation to their age. In conclusion, the older the student gets, the clearer his/her visual and auditory learning perception will be.

\section{CONCLUSION}

Many recent studies have focused on learning styles. Teachers or people involved in scientific works should benefit from this research. Teachers and scientists should study the research results and apply the findings in the class environment. If necessary, they can communicate with other people studying in this field. As mentioned before, technological developments provide us with this opportunity.

In both pre-service and in-service education, it is vital that teacher candidates be educated as being aware of the learning styles. The students should also think wisely and, with the about guidance of teachers, apply their knowledge. They need to be critical and creative in learning how to learn. This kind of awareness not 
only supports learning but also improves the student's self-confidence.

To increase the efficiency of learning styles in learning process, firstly, it may be beneficial to explain illustratively how students benefit from learning styles. In addition, methods-techniques and materials taking the learning styles of students into consideration can be used by the teachers. Teachers can also guide the parents in providing learning conditions suitable for the students' learning styles.

\section{REFERENCES}

1. Erden, M. and S. Altun, 2006. Learning Styles. İstanbul: Morpa Culture Publications. ISBN: 9752844863.

2. Kazu, I.Y., H. Kazu and O. Ozdemir, 2005. The effects of mastery learning model on the success of the students who attended usage of basic information technologies course. Educ. Technol. Soci., 8: 233-243. http://www.ifets.info/journals/8_4/21.pdf

3. Özbek, Ö., 2007. Determination of primary school students: Learning styles. Proceeding of the 16th National Education Sciences Congress, Sept. 5-7, Gaziosmanpaşa University, Tokat, ISBN: 978-9757328-43-8, pp: 173-176.

4. McCarthy, B., 1987. The 4MAT System: Teaching to Learning Styles with Right/Left Mode Techniques. 2nd Edn., Excel, Inc., Barrington, ISBN: 0960899200, pp: 220.

5. McCarthy, B., 1982. Improving staff development through CBAM and 4MAT. Educ. Leadership, 40: $20-25$.

http://eric.ed.gov/ERICWebPortal/custom/portlets/ recordDetails/detailmini.jsp?_nfpb=true\&_\&ERIC ExtSearch_SearchValue_0=EJ269892\&ERICExtS earch_SearchType_0=no\&accno=EJ269892

6. McCarthy, B., 1985. What 4MAT training teaches us about staff development? Educ. Leadership, 42: 61-68.

http://eric.ed.gov/ERICWebPortal/custom/portlets/ recordDetails/detailmini.jsp?_nfpb=true\&_\&ERIC ExtSearch_SearchValue_0=EJ319802\&ERICExtS earch_SearchType_0=no\&accno=EJ319802

7. McCarthy, B., 1990. Using the 4MAT system to bring learning styles to schools. Educational Leadership, $\quad$ 48: 31-37. http://eric.ed.gov/ERICWebPortal/custom/portlets/ recordDetails/detailmini.jsp?_nfpb=true\&_\&ERIC ExtSearch_SearchValue_0=EJ416429\&ERICExtS earch_SearchType_0=no\&accno=EJ416429
8. McCarthy, B., 1997. A tale of four learners: 4MAT's learning styles. Educational Leadership, 54: 46-51.

http://eric.ed.gov/ERICWebPortal/custom/portlets/ recordDetails/detailmini.jsp?_nfpb=true\&_\&ERIC ExtSearch_SearchValue_0=EJ540880\&ERICExtS earch_SearchType_0=no\&accno=EJ540880

9. McCarthy, B., 2000. About Teaching 4MAT in the Classroom. About Learning, Inc., Wauconda, IL., ISBN: 1-929040-01-6.

10. Schmeck, R.R., 1983. Learning Styles of College Students. In: In Dividual Differences in Cognition, Dillon, R.F. and R.R. Schmeck (Eds.). Academic Press, New York, ISBN: 9780122164019

11. Kaplan, E.J. and D.A. Kies, 1995. Teaching styles and learning styles. J. Instruct. Psychol., 22: 29-34.

12. Boydak, A., 2001. Learning Styles. Beyaz Publication, Istanbul, ISBN: 9789755990477, pp: 128.

13. Carroll, A., 2001. How to Study Better and Faster Using your Learning Styles and Strengths. J. Weston Walch Publisher, Portland, Maine, ISBN: 0825142474.

14. Grasha, A.F., 1996. Teaching With Style. Pittsburgh, Alliance, PA., ISBN: 0964507110, pp: 386.

15. Diaz, D.P. and Cartnal, R.B., 1999. Students learning styles in two classes. Online distance learning and equivalent. College Teach., 47: 130135.

http://eric.ed.gov/ERICWebPortal/custom/portlets/ recordDetails/detailmini.jsp?_nfpb=true\&_\&ERIC ExtSearch_SearchValue_0=EJ606686\&ERICExtS earch_SearchType_0=no\&accno=EJ606686

16. Jonassen, D.H., 1983. Designing Constructivist Learning Environments. In: Instructional Design Theories and Models: A New Paradigm of Instructional Technology, Reigeluth CM. (Eds). Lawrence Erlbaum Associates, Mahwah, NJ., ISBN: 0805828591, 9780805828597. pp: 215-241.

17. Butler, K.A., 1988. Learning and teaching stylesIn theory and practice. Columbia CT: The Learner's Dimension. ISBN-10: 0945852002, pp: 318.

18. Allport, G.W., 1961. Pattern and Growth in Personality. Holt, Rinehart and Winston, New York, ISBN: 10: 0030108101, pp: 608.

19. Şimşek, A., 2004. Learning Style. In: Individual Differences in Education, Deryakulu, D. and Y. Kuzgun (Eds.) Nobel Publication, Ankara, ISBN: 975-591-610-5, pp: 352. 
20. Peavler, R., 2007. Learning styles and the collegiate voice studio supplementary. Material Northeast Chapter Regional Conference College Music Society, Mar. 24, pp: 1-29. http://www.arts.iup.edu/facmus/rpeavler/handout.p df

21. Keefe, J.W., 1987. Learning Style: Theory and Practice. National Association of Secondary School Principals, Reston, VA., ISBN: 0-88210201-X, pp: 53.

22. Hasirc1, Ö., 2006. Learning Styles of Students of Classroom Teaching Department. J. Theory Practice Educ., 2: 17-18. ISSN: 1304-9496. http://eku.comu.edu.tr/index/2/1/okhasirci.pdf

23. Felder, R.M. and R. Brent, 2005. Understanding student differences. J. Eng. Educ., 94: 57-72. http://www4.ncsu.edu/unity/lockers/users/f/felder/p ublic/Papers/Understanding_Differences.pdf

24. Reinert, H., 1976. One picture is worth a thousand words? Not necessarily. Modern Language J., 60: 160-168.

http://www.newhorizons.org/strategies/styles/reine rt.htm

25. Boyatzis, R. E. Kolb, D. A. \& Mainemelis, C. (2000) Experiential Learning Theory: Previous Research and New Directions. IN: Sternberg, R. J. \& Zhang, L. F. (Eds.). Perspectives on cognitive, learning, and thinking styles. NJ: Lawrence Erlbaum.http://www.learningfromexperience.com/i mages/uploads/experiential-learning-theory.pdf

26. Özden, Y., 2005. Learning and Teaching. Pegem a Publication, Ankara, ISBN: 975-6802-13-8.

27. Kolb, D.A., 1984. Experiential Learning: Experience as the Source of Learning and Development. Prentice Hall, New Jersey, ISBN: 10: 0-13-295261-0.

28. Adler, R.W., R.H. Whiting and K. Wynn-Williams, 2004. Student-led and teacher-led case presentations: Empirical evidence about learning styles in an accounting course. Account. Educ., 13: 213-229. DOI: 10.1080/09639280410001676620.

29. Veznedaroğlu, R.L. and O. Özgür, 2005. Learning styles: Definitions, models and their functions. J. Primary School Online, 4: 1-16. http://ilkogretimonline.org.tr/vol4say $2 / \mathrm{v} 04 \mathrm{~s} 02 \mathrm{~m} 1 . \mathrm{pdf}$

30. Legendre, P. and L. Legendre, 1998. Numerical Ecology. 2nd Edn., Science BV Amsterdam, Elsevier, ISBN: 0444892508, 9780444892508. http://books.google.com/books?id=KBoHuoNRO5 $\mathrm{MC} \&$ printsec $=$ frontcover\&hl=tr
31. Çayc1, B. and E. Ünal, 2007. Investigation of classroom teacher candidates in terms of various variables. J. Sci. Educ. Thought, 7: 1-6. http://www.universitetoplum.org/text.php3?id=328

32. Coffield, F., 2004. Learning Styles and Pedagogy in Post-16 Learning: A Systematic and Critical Review. Learning and Skills Research Centre, London, ISBN: 18533891889781853389184

33. Kazu, I.Y. and N. Yavuzalp, 2008. An analysis of the primary school teachers' usage of instructional software. Int. J. Emerg. Technol. Learn., 3: 45-53. http://online-journals.org/ijet/author/submission/150

34. Biggs, J., 2001. Enhancing Learning: A Matter of Style or Approach? In: Perspectives on Thinking, Learning and Cognitive Styles, Sternberg, R.J. and L.F. Zhang (Eds.). Mahwah, Lawrance Erlbaum Associates, NJ., ISBN: 0-8058-3431-1, pp: 276.

35. Temel, A., 2002. Do you know your learning style? Educat. Sci., 48: 6-9. http://www.basariyolu.com/yazarlar.asp?id=132.

36. Açıkgöz, K.Ü., 1996. Effective Learning and Teaching. İzmir: Kanyılmaz Publication. ISBN: 9789750199127, pp: 407.

37. Mc Keachie, W.J., 1995. Learning styles can become learning strategies. ISSN: 1057-2880. http://www.ntlf.com/html/pi/9511/v4n6.pdf

38. Fidan, N., 1986. Learning and Teaching at School, Concepts, Principles, Methods. Ankara: Kadıoğlu Publication. ISBN: 975-337-043-1.

39. Çelenk, S. and Ö. Karakış, 2007. The different learning style levels of students in some higher education institutions. Proceeding of the 16th National Eduction Sciences Congress, Sept. 5-7, Gaziosmanpaşa University, Tokat. ISBN: 978-9757328-43-8, pp: 374-382.

40. Dunn, R. and K. Dunn, 1992. Teaching Elementary Students Through their Individual Learning Styles: Practical Approach for Grades 3-6. Allyn and Bacon, Massachusetts, ISBN: 10: 0205132219, pp: 529.

41. Keefe, J.W., 1979. Learning Style: An Overview. In NASSP's Student Learning Styles: Diagnosing and Prescribing Programs. National Association of Secondary School Principals, Reston, VA., ISBN: $088210103 x$, pp: 137.

42. Jonassen, H.D. and B.L. Grobowski, 1993. Handbook of Individual Differences, Learning and Instruction. 1st Edn., Lawrance Erlbaum Associates, USA., ISBN: 10: 0805814132, pp: 512. 
43. Coffield, F., D. Moseley, E. Hall and K. Ecclestone, 2004. Should we be using learning styles? What research has to say to practice? Learn. Skills Res. Centre. ISBN: 185338814 5. pp: 1-5. http://www.lsda.org.uk/files/PDF/1540.pdf

44. Felder, R.M. and L.K. Silverman, 1988. Learning and teaching styles in engineering education. Eng. Educ., 78: 674-681. http://www.eric.ed.gov/ERICWebPortal/custom/po rtlets/recordDetails/detailmini.jsp?_nfpb=true\&_\& ERICExtSearch_SearchValue_0=EJ372622\&ERIC ExtSearch_SearchType_0=no\&accno=EJ372622

45. Della-Dora, D. and L.J. Blanchard, 1979. Moving Toward Self-Directed Learning: Highlights of Relevant Research and of Promising Practices. Association for Supervision and Curriculum Development, Alexandria, Virginia, ISBN: 13: 9780871200945, pp: 96.
46. Dunn, R. and K. Dunn, 1978. Teaching Students Through their Individual Learning Styles: A Practical Approach. Prentice Hall, Reston, VA., ISBN: 10: 0879098082, pp: 336.

47. Entwistle, N.J., 1981. Styles of Learning and Teaching: An Integrated Outline of Educational Psychology for Students, Teachers and Lecturers. Wiley, Chichester, ISBN: 10: 0471279013, pp: 306.

48. Dunn, R. and K. Dunn, 1993. Teaching Secondary Students Through their Individual Learning Styles. Allyn and Bacon, Boston, ISBN: 10: 0205133088, pp: 496. 